\title{
Animacy, Abstraction, and Affect in the Andean Past: Toward a Relational Approach to Art
}

\author{
Elizabeth DeMarrais
}

Received 28 Apr 2017; Accepted 14 Aug 2017; Revised 14 Aug 2017

In this article, I set out a relational approach to Andean art, with the aim of investigating, in broad terms, the making, viewing and experience of art among preHispanic peoples. The analysis draws upon the ideas of art historians, as well as upon the work of ethnographers and archaeologists, to integrate theoretical approaches that consider animacy and the ways art objects gain significance as part of assemblages. Examining four aspects of Andean art: (1) insistence; (2) abstraction; (3) networks and linkages; and (4) affect and embodied experience, I conclude that the term 'art' (as an analytic category) overlaps poorly with Andean categories of cognition, sociality and material practice. Archaeologists can usefully refocus attention on the ways these craft items were made, used in daily life, displayed in rituals and ultimately deposited in the places where they were found.

There really is no such thing as Art. There are only artists. Once these were men who took coloured earth and roughed out the forms of a bison on the wall of a cave; today they buy their paints, and design posters for the Underground; they did many things in between. There is no harm in calling all these activities art as long as we keep in mind that such a word may mean very different things in different times and places, and as long as we realize that Art with a capital A has no existence

Gombrich 1950, 5

It has taken a long time for Andean objects to be admired as works of art by Westerners 
... aesthetic inventions enlarge human awareness directly with new ways of experiencing the universe

Kubler 1962, 65

\section{Introduction}

Three quotations from art historians frame this essay on the relevance of the term 'art' for archaeologists. Gombrich's words opened his book, The Story of Art, and -in my view - they dispense with the need for an extended debate about terms. Esther Pasztory, in turn, reminds us that the art of the pre-Hispanic Andes was not readily appreciated by Westerners. This may have been due to artisans' choices of media, as well as their frequent reliance on abstraction, both themes to be explored in this article. Third, in formulating insights about the effects of pre-Columbian art on its intended (indigenous) audiences, George Kubler highlighted affective response. Art has, over millennia, evoked reactions ranging from delight, interest and curiosity to awe, wonder and fear. As it does so, art encourages audiences to see their world in novel ways.

Taking up these themes, I investigate the making, viewing and experience of art among pre-Hispanic peoples of the Andes from a broad perspective. My central aim is to build a case for a relational approach to art, in line with recent theoretical debates that consider animacy and the ways objects gain significance as part of assemblages. In agreement with Gombrich, I argue that neither 'Art' nor 'art' are particularly useful terms for characterizing the diverse assemblage of craft items produced in the Andes of the past. The Andean corpus incorporates numerous 'powerful objects' that sit awkwardly within the categories of Western art; many of these crafted items are better discussed, where possible, in the context of wider social networks linking people and non-human actors. 


\section{Animacy}

Ethnographers and archaeologists working in the Andes (Abercrombie 1998; Allen 1988; Bray 2015; D’Altroy 2016; DeMarrais in press; Gose 1994; Sillar 2009; Swenson 2014) acknowledge the centrality of animacy perspectives for the interpretation of social relations. Drawing upon the arguments of material-relational and nonrepresentational approaches (Barad 2003; Bennett 2010; Jennings \& Swenson 2017; Swenson 2014), these scholars argue that agency is located in social actors, human and non-human, who engage in ongoing co-creation of the world. Meaningful social interaction in the Andean past (and present) frequently involved a world that was seen as animated, 'potentially alive and imbued with spirit' (Allen 2015, 24).

As D'Altroy $(2016,418-19)$ has observed:

In Andean eyes ... [t] he world or cosmos was replete with sentient beings-humans present, ancestors past, eternal places on the landscape, and celestial, terrestrial, and marine deities. Each of those actors was physically present, interacting with the others in a complex interplay of mutual sustenance ...

Interaction was phrased in terms of reciprocity and moral obligation. All thingsmountain peaks, ancestors, shrines - and art-could be energetic, agentive and communicative, and many were imbued with 'sami', a vital life force that circulates through the things of the world (Allen 1998).

An animacy worldview emphasizes reciprocity; care for things (houses, art, objects, ancestors, or agricultural fields) and animals is thought to be reciprocated by renewed fertility and well-being (Sillar 2009). In turn, activities in the world generate complicated configurations of people and things, framed in terms of moral principles. Repeated pouring of libations and the offering or sharing of coca leaves 
maintains balance in relationships and helps to rectify inevitable asymmetries as they arise (Urton 1997).

Archaeologists need to acknowledge that these perspectives, primarily documented by ethnographers or scholars working with Inka-era documentary sources, cannot be extended, uncritically, into the deep past. Similarly, the diversity of subjects, media, and forms of Andean art cautions us against essentializing patterns in art across time and space in the Andes. Yet, at the same time, the implications of an animacy approach are far-reaching, as illustrated by Allen (2015, 36), who recently cited Gose (1996) and Curatola (2008) to argue that the Inka state is best seen as 'an immense and delicate meshwork of personal relations woven by the Inka ruler, the impalpable and fragile strands of which had to be constantly reinforced and renewed' (Allen's translation of Curatola 2008, 57). Finely crafted objects were crucial to the forging and maintenance of these relationships.

In the pages that follow, I argue that animacy approaches, taken seriously, require a rethink not only of our analytical categories and our understanding of Inka politics (see D'Altroy 2016), but also of our theoretical understandings of the significance of art.

\section{Andean art as powerful objects}

The boundaries distinguishing a category of art from more quotidian things in the Andes can rarely be drawn clearly. According to animacy perspectives, for many Andeans (past and present) places in the landscape, human beings, animals and a wide range of objects will at times manifest 'an inherent, internally generated liveliness or power ... [known as] sami...; [in turn] Samiyuq connotes a kind of genius or ebullient spirit ... [the] flow of enlivening spirit, inherent in all matter, is similar in principle ... to our concept of energy'. Sami can be harnessed or managed by human beings; indeed, much Andean ritual 'works at holding, controlling, and directing the flow of sami' (Allen 1988, 50). 
A researcher's understanding of the significance of a flow of sami from artisan to textile, or from a shrine (or $w a k^{\prime} a$ ) to those engaged in pouring libations or making offerings, must be built up through careful analysis of human engagements (thinking, actions, effort, and skill) with places and the (non-human) things of the world (Allen 1998; 2015; Jennings \& Swenson 2017; Sillar 2009; Swenson 2014). Informed by ethnographies (Abercrombie 1998; Allen 1998; Gose 1994), we can consider the effects of powerful objects that include art, asking about the ways that transfers of vital powers influenced both people and the patterning of the archaeological record.

As an example, an Andean $w a k^{\prime} a$ could be as simple as a slightly modified stone, still recognizable as a boulder. Some of the Inka empire's most potent cult objects were overlooked by Spaniards who failed to recognize that a 'rough stone' could be a powerful place (Cobo [1653] 1990, cited in Sillar 2009, 370). Because sami circulates through the world, boundaries separating human beings from non-human things and places are also fuzzy. Stone walls were at times left un-plastered, revealing individual stones (Bray 2015). Likewise, the essence of an object appears to have derived at least in part from its location in the landscape; striking examples include boulders that were transported over vast distances in Inka times, presumably to transfer the essence of a place of origin, contained within the stone, to a new location (Ogburn 2004).

At the other end of the spectrum, some Andean crafted objects, particularly woven tunics and metalwork, reveal extraordinary levels of skill and hours of painstaking labour. Disproportionately, these objects were portable things; some were used in activities of daily life and in ritual, others were displayed or worn as markers of status or ethnicity, and some were placed in burials. Virtuosity or highly skilled production of textiles, metal and lapidary work, and ceramics characterize a significant proportion (though by no means all) of the corpus of visually striking crafted objects. In addition to these portable items, stone working was widespread, particularly in Inka times, from slight modifications made to outcrops or boulders, to 
painstaking efforts to fit enormous wall stones precisely together to create imposing walls or façades. Still other stones were intricately carved wak'as (Jennings \& Swenson 2017).

Over the whole of the Andean sequence, artisans devoted labour, skill, inventiveness, knowledge, attention and time to a diverse range of crafts. Any overview, such as this one, inevitably involves generalizations, as well as the risk of obscuring local differences. However, the virtuosity manifested by so many preHispanic Andean artisans, across a diverse collection of objects and media, at different times and places, invites intriguing questions about the roles and significance of Andean art.

\section{Andean art: abstraction, spatial order, and structural relations}

Building upon the observations made in the last section, we can ask: Why did Andeans make so much art emphasizing abstraction (Ascher \& Ascher 1981; Pasztory 1997), spatial order (Stone-Miller \& McEwan 1990/91) and structural relations (Lechtman 1984)? A number of art historians draw attention to the paucity of narratives (or figurative scenes) in art of the Andean past (Pasztory 1997; Pillsbury 2009; Stone-Miller \& McEwan 1990/91). They argue that Andean art is often abstract (or conventionalized), revealing preoccupation with 'spatial relations [and] mental patterns' (Pasztory 1997, 64). Inka art, in particular, reveals a surprising absence of figuration or portraits of individual emperors;, indeed, Inka art, with its emphasis on finely detailed geometric patterns, is unusual among early empires (D'Altroy 2016).

Trends toward abstraction, geometric patterns and repetition are perhaps most obvious in Inka art (Fig. 1), although the walls of earlier Chimú palaces on the north coast of Peru (AD 1000-1400) were decorated with adobe friezes (Fig. 2) that replicate the layouts and intricate patterns that were woven into tapestry (Fig 3). Pillsbury $(2009,82-3)$ likens Chimú adobe friezes to wallpaper, executed on a vast scale, to inspire 'awe, wonder, and [a sense of] mystery'. For both of these powerful 
later Andean polities, then, prominent art emphasized pattern, symmetry, and repetition.

$<$ Figures 1, 2, 3 near here $>$

Art historians draw a useful contrast between conceptual art (concerned with what the artist knows in his or her mind) and perceptual art (what is seen by the artist in the world). On a general level, the Inka tunic and the Chimú examples discussed here are conceptual, rather than perceptual art, exploring themes of abstraction, repetition and relationships among constituent elements. Yet we are left to ask: Why did Andean artisans frequently favour conceptual over perceptual art, and why did this trend prevail over many centuries?

Possible answers are set out below, but in anticipation of exceptions, I qualify the question by noting that, among the most obvious examples of Andean perceptual art, Moche (c. AD 200-800) fine-line drawings and portrait vessels stand out. Richly figurative, these vessels express themes and/or narratives that have been widely published (Castillo et al. 2008; McClelland et al. 2007; Quilter 1990; 1997). Moche portrait pots (Donnan 2004) and some Paracas and Nasca textiles (Paul 1991) and ceramics (Kroeber \& Collier 1998; Proulx 2007) are also obviously figurative. Peru's earliest figurative art, from earlier Preceramic and Initial Periods, has been described and discussed by Burger (2007).

Some Chavín art (Early Horizon, c. 800-200 BC) may be characterized as figurative, although its makers appear to have been more concerned with themes of human-animal transformation, part-to-whole relationships (Urton 2008) and references to the supernatural (Burger 1992). Images frequently juxtapose human and animal features, blurring the lines separating human from non-human forms (see further discussion below). A well-known Chavín stone carving, referred to as the supreme deity (Burger 1992), combines anthropomorphic and zoomorphic features (Fig. 4) (Conklin \& Quilter 2008; Diessl 2004). Chavín art suggests 
associations with, or aspects of, the supernatural, and the balancing of opposing forces. The point to emphasize is that, for these examples, the boundaries separating humans, non-humans and places appear fuzzier in the artist's perspective than they would be for contemporary Westerners.

$<$ Figure 4 near here $>$

Other exceptions to the tendency toward abstraction include Inka gold and silver figurines, which are generically male or female human beings or camelids. Far more ubiquitous, and visible in the Inka provinces, were aríbalos (Bray 2003) decorated with finely executed geometric motifs (Fig. 5). The aríbalo, used for serving chicha [maize beer] at large-scale feasts sponsored by the state, was crucial to the empire's expression of reciprocity through hospitality. Unkus [finely-woven tunics], in turn, indicated the status of their wearers. As items of display, both objects, covered in intricate and repetitive geometric designs that were emblematic of the state, helped to mediate social relations in an empire that integrated over 80 distinct ethnic groups.

$<$ Figure 5 near here $>$

The particular importance of finely woven cloth for Inka diplomacy was articulated long ago by Murra (1962). Finely woven garments marked the status or ethnic identity of their wearers. Others have extended Murra's arguments for 'textile primacy' in the longue durée of the Andes (Costin 1998; Stone-Miller \& McEwan 1990/91, 53-80). Supporting evidence includes the incredible virtuosity of weavers over time, exemplified by an extraordinary range of techniques ${ }^{2}$ and frequent replication of textile motifs in other media (such as the highly visible carved stonework on Tiwanaku's 'Gate of the Sun': Bennett 1954, 72), or the transfer of Chimú textile designs to adorn the adobe walls of Chan Chan (discussed earlier). 
More recently, Allen (1998, 25), discussing the particularly elaborate Inka unku, or tunic, now at Dumbarton Oaks (Fig. 1) from an ethnographic perspective, wrote that:

This spectacular garment, with its bewildering array of toqap $u^{3}$ designs, must have been woven for a powerful personage of high status. Toqapu designs seem to have been emblematic of social statuses (for example, Zuidema 1991, 1994); thus one might speculate that this textile, which encloses a variety of toqapu designs, announces the wearer's ability to dominate (and in that sense 'enclose') a multitude of complex relationships. In a 'total' statement about cosmic, imperial, and personal power (Mauss 1969, 1-5), the wearer displays himself as kamachikuq, the authority, 'the one who keeps order'.

In the absence of writing (and a shared language), material culture would have been especially important for materializing socio-political institutions, for rituals of solidarity, for expressing ethnicity and for messages about power relations (DeMarrais 2011; 2016; DeMarrais et al. 1996;). Under the Inkas, portable objects were crucial for the state's reach into (and presence in) new territories (Allen 2002, 2015; Bray 2003). Through their essences and personal associations, as gifts and as tokens of personal relationship, their presence reinforced as well as re-aligned obligations of reciprocity, as discussed in greater detail below.

\section{Toward a relational view of Andean art}

In this section, I discuss four themes, or trends, relevant for building a relational approach to Andean art: (1) insistence; (2) abstraction; (3) networks and linkages; and (4) affect. My aim is to synthesize insights from the art history literature with arguments of ethnographers and archaeologists who are exploring animacy perspectives. While space limitations do not permit a detailed case study, I seek to 
demonstrate that investigating the art of the Andes as elements in (or constituent parts of) wider assemblages (and networks) can help us to make sense of observed patterns.

\section{Insistence}

Khipu, the knotted webs of strings associated with both Inka and Wari accounting and memory practices (Conklin 2002), are emblematic for many researchers, who argue that they signify a specifically Andean mode of thought or mental process (Fig. 6). In an early study of Inka khipu, Ascher and Ascher (1981) drew upon Gertrude Stein's literary notion of 'insistence', or repetition for emphasis, to refer to an Andean 'way of doing things' or the 'predominant style of a culture'. In the Aschers' view, insistence in the Andes (especially during the Inka era) involved 'a focus on conceptual networks, which include kinship ties, the procurement of goods from different ecological zones, the quipu recording device, and the various arts, especially textiles' (Pasztory 1997, 68). Inka material culture manifests repetition and orderly arrangements, seen in the sequences of knots that comprise a khipu and in finely detailed geometric motifs (woven into textiles or adorning aríbalos), as well as in the regularity of terraces built like steps into a slope or lines of qollqa [Inka storehouses] (Ascher \& Ascher 1981, 43-54).

$<$ Figure 6 near here $>$

Setting the Inka patterns into the wider context of Andean art, Allen $(1998,19)$ observes that 'Some Andean styles tend toward angularity and a particular kind of abstraction that is achieved through play with dimensionality (for example, Sawyer 1963). Both these tendencies found an extreme expression in Inca visual art, with its intense focus on enclosure and angularity ... . Inca artists seem to have been fascinated with geometric relations: with encounters, reflections, inversions, and repetition'. While Allen stresses trends in the wider Andean corpus, she also draws 
attention to a particularly careful ordering of the world undertaken by Inka artisans. These patterns, executed in khipu and textile structure, were scaled up, creating symmetries in architecture, terraces and landscape.

A further characteristic of Inka art is its corporate insistence (D'Altroy 2016). In the Inka case, oral traditions (recorded by the Spaniards) contain numerous details of the identities, lives and ayllu [kin group] affiliations of emperors, detailing political and military achievements. Surprisingly, material representations of these rulers are largely absent; the archaeological record is instead more thematically corporate. ${ }^{4}$ Collective tendencies are present in other Andean contexts of making craft items, as I have argued elsewhere (DeMarrais 2013b). Specifically, in heterarchically ordered settings in smaller-scale societies, the making of art was frequently more communal, as a shared activity set in households. In such contexts, more than one artisan could easily have contributed to making visually distinctive objects; moreover, as valued objects, with shared authorship, they also may have been owned or curated by a kin group rather than a single family (Dissanayake 1995; Hirth 2009).

Acknowledging the importance of collective endeavours for building and sustaining social relations makes it easier, perhaps, to differentiate the corporate insistence of Andean artworks from a countervailing tradition in the Western art world that seeks to attribute artworks to single individuals. To give an example, collective effort is clearly visible in Wari architecture as well as in textiles from the Middle Horizon (c. AD 650-1000). Stone-Miller \& McEwan (1990/1991, 57) describe labour-intensive projects in Wari sites that materialized the state's efforts to generate a corporate sense of order in both art and architecture. They suggest that ‘[a]rchitecture is more socially expressive, costume more personally so, although there is a degree of overlap'. Just as the rectilinear walls of Pikillacta (Fig. 7) required pre-planning, built up gradually from their foundations, so, they argue, were threads intricately woven together to create the finest Middle Horizon tunics (Fig. 8). Both additive technologies, the work was likely shared out; stone walls could be 
extended, just as individually woven sections of cloth could be sewn together to assemble a completed tunic. Wari tunics, presumably worn by state officials, incorporate as many as 7-9 miles of thread (for one exceptional example, the estimate rises to 18 miles). With highly saturated colours and complex geometries, tunics suggest 'full exploitation' of the possibilities of tapestry techniques and countless hours of skilled labour (Bergh 2012, 160).

$<$ Figures 7 \& 8 near here $>$

Collective labour informs the study of social relations, in the sense that working together builds solidarity and a sense of shared goals or benefits. As Murray and Mills $(2013,136-7)$ have argued, agency is 'constrained and enabled by one's connectivities with other people. In this sense, agency is not what an individual can do, but how a person participates in a multitude of intersecting social relations.' The relative permanence of architecture and certain other craft goods further extend social relations in time, reminding participants of past shared activities.

To return to the notion of insistence (and repetition for emphasis), it is interesting that the Aschers chose a term from literary criticism to characterize Inka (and Andean) material culture, which (in the absence of writing) stands in for some of the communication achieved in other areas of the world by texts. Of course, material culture (and especially costume) is integral to speeches and events, which may also have involved repetition of phrases for emphasis. More generally, the concept of insistence has value for highlighting recurrent trends within different media and art forms, but also for helping us to see ways that these trends, in scaledup forms, were also part of the ordering of the built environment. 


\section{Abstraction}

In art, abstraction involves, simply, the absence of figuration or naturalistic depictions, or it can entail the elimination of detail or the simplification of form (Pasztory $(1990 / 1991,114)$, perhaps as a means to emphasize interconnections among the elements that remain. Alternatively, abstraction may highlight an underlying pattern. In Western settings, modern conceptual art demands greater effort from its audiences than does a traditional landscape, seascape or still-life painting (Pasztory 2005, 139), and some Andean art requires similar effort, particularly for those unfamiliar with its conventions.

In this section, I draw attention to abstraction in Andean art that suggests makers' efforts to express a concept, to express a relationship, or to convey a sense of order. The abstraction seen in Inka art suggests a fascination with geometry, dimensionality and mathematics (Urton 1997). Similarly, standardization of motifs woven into Wari tunics involved repetition with modification in orientations, scale and colour combinations. Additionally, the compression of motifs across the width of some Wari tunics accommodated the shape of the wearer's body, to maintain the (visual) integrity of geometric patterns while the tunic was being worn. Wari weavers applied rule-governed distortions to motifs, systematically compressing stylized figures (birds and camelids (or deer)), as described recently by Bergh (2012; see also Sawyer 1982). As the most highly visible and elaborate portable objects produced by Wari artisans, Bergh $(2012,188)$ further surmises that when Wari elites wore tunics, they associated themselves with supernatural beings and their numerous attendants. The ordering and layout of the designs may also have signalled rank, while 'insistent dualism' $(2012,189)$ seen in the pairing of figures drew attention to principles of reciprocity or to the capacity of the wearer to reconcile conflicting forces or tensions, both 'cosmic and human ... The tunics' color patterns, which so strongly emphasize the even, balanced distribution of paired 
directional oppositions or paired alternations, may have amplified this message whether or not they carried other meanings' (Bergh 2012, 189).

A tunic is obviously a single object, intended to be worn and seen by an audience. One intriguing question about Wari principles of abstraction, or the rulegoverned distortion of a tunic's constituent motifs, is whether textile layouts might also have conveyed relational principles (such as those concerned with vital powers, or efficacy, with respect to a motif's position within an overall design). More generally, the abstraction found on other Andean artworks suggests the makers' efforts to impose (or to convey) simplicity, order, duality, or symmetry in objects used in display as well as in ritual. Abstract and repetitive designs inherently draw attention to relationships among constituent elements. Moreover, their prevalence in the pre-Hispanic Andean assemblage (at the expense of more figurative art) points toward an ongoing concern for materially expressing, and perhaps even re-working, existing principles of order.

\section{Networks, nodes, and linkages}

Relational approaches, by definition, also stress an understanding of links between and among objects, as well as the positioning of separate elements in relation to one another. In this sense, a khipu resembles a textile, although its technology is distinctive (see Fig. 6). Each constituent cord was created separately, while information was encoded in colour, directionality, spinning, doubling, plying and knotting (Conklin 2002, 59). The khipu structure as a whole was mirrored in the large-scale $z e q^{\prime} e$ system created by the Inka, a series of invisible lines extending across the landscape from Cuzco. The zeq'e lines, like the individual threads of the khipu, tied shrines and other sacred locations together, generating a network that was symbolic as much as it was practical (D'Altroy 2015; Pasztory 1997, 63).

Art historian Pasztory $(2005,64)$ observes further that the idea we now have of Andean art is of a tradition that was not, for the most part, based on picturing or 
reproducing the world, but on constructing mental diagrams of it. In this system, the actual artefacts or places are nodes within larger networks'.

In a similar manner, animacy perspectives reveal that, from the perspective of an individual (or that of a specific object), lasting social relationships were created and sustained through offerings of libations and reciprocal care. Discussing a textile from an ethnographic perspective, Allen $(2015,31)$ observes this process:

[the] ... completed textile-creature has its own wants and needs -in a continuing cycle of reciprocal appropriation, it receives a libation from the weaver, who asks it to stay strong, to keep the wearer warm, and to not wear out ... This is not symbolism. The textile's personhood is not a symbolic correspondence in which textile stands for the person. It is more useful to think of the relationship in terms of 'distributed personhood.' ... The woven garment participates in a distributed personhood because it becomes a locus of creative agency ... transmitted by the weaver in a kind of personhood that extends into multiple sites beyond the boundaries of the body ...

Crafted objects, ancestors, and powerful places, are-and were in the past-jointly implicated in complex webs of kinship (Bray 2009; Sillar 2009), framed by the principles of reciprocity. Moreover, intrinsic properties of a craft item-such as its maker (or makers), place of origin, materiality, and history of ownership were-as much as its visual attributes - integral to its ontological significance at any given time.

One wider implication is that contexts of making and use, as well as position or participation in a network, are crucial to interpretations. Seeking detailed contextual information is not always simple for archaeologists, although investigating deposition, in the form of a cache, archive, bundle, or burial, is one direction for these investigations (see discussion in DeMarrais in press; Murray \& Mills 2013; Zedeño 2008, 2013;). We might also envision the khipu being read, as illustrated in 
Figure 6, or a frieze at Chan Chan, as seen in Figure 2, positioned for visibility by the audience entering the compound. I expect that further exploration of the principles of order and structure expressed in Andean art-and sometimes mirrored in architectural forms and the wider landscape (as discussed for the Wari and Inka examples above) - might also provide new insights about past contexts of making and use.

\section{Beyond visuality: affective and embodied experiences}

The study of art leads to a focus on visual aspects of objects, as well as their varied effects on viewers (or audiences). For example, we surmise that the use of a discontinuous warp indicates that Andean weavers wanted to create eye-catching bold and highly saturated colours, since the technique is labour intensive. Similarly, depletion-gilding of metals (e.g. removal of copper from a copper-gold alloy using acid) produced a purified gold surface. More costly than gilding, the former practice created the essence, or purity, that for Andeans appears to have been as important as visual appearance. Pasztory $(1997,64)$ further argues that the 'concept of essences would seem to indicate that to Andeans materials were more aesthetically and religiously powerful if they were somehow pure and solid throughout'. Her observation coincides with arguments (made earlier) that the efficacy or vitality of a craft item depended upon essence, materiality and place of origin as well as upon its position within a network of relationships.

Discontinuous warp techniques and depletion-gilding reflect the importance of visual impact, as well as intrinsic qualities, of cloth and metals, respectively. Material culture theorists also consider art in terms of an object's (or an assemblage's) influence on the experience of viewers. In a recent article, I investigated elaborately painted infant burial urns in northwest Argentina (DeMarrais 2013a) (Fig. 9), building upon the work of Kubler (1962, and above) and Armstrong (1971, 43) to consider the affective realm as a 'universe of [human] interiority ... [whose] mode of address is direct' and viscerally felt. I suggested that decorated burial urns, 
each a unique object, displayed in rituals after infant death, evoked strong affective responses. For Armstrong $(1971,5)$, the 'affecting presence' involves an artwork for which 'presentation, not representation, is the goal of the artist.' Armstrong's notion of an affecting presence was not formulated with animacy perspectives in mind; however, the affecting presence (as conceived by Armstrong) of a single art object might be analytically strengthened if we could establish the nature of associations with makers, owners, viewers and other relevant (human or non-human) social actors. In the case of the urns, attempts to situate the vessels in ritual practices, such as a funeral taking place over an extended period of time, may prove fruitful.

$<$ Figure 9 near here $>$

More generally, in a ritual setting, art is linked to action, to doing as well as viewing (DeMarrais \& Robb 2013). Emphasis on activities further reinforces the fact that affect and emotion are embodied experiences, simultaneously mental and physical states of being. As a performance is repeated, memories, affects, and past experiences are linked with experiences unfolding in the present. Emotions evoked in rituals may encompass a sense of wonder, awe, revulsion, fear, or a mix of changing affects and emotions. The 'cultural crafting and expression of emotions' is intrinsic to ritual encounters (Kus 2010, 168), while, as Gosden $(2004,38)$ observes, rituals not only evoke emotions; these events also bring them into being.

Because art was used actively by past Andean people to mediate ritual, for diplomacy, and to forge and sustain social relationships, inquiry into the forms of art, the nature of its affecting presence(s), and associations among objects hint at the emotional valences of those rituals. Objects could-and probably often did-inspire strong emotions that had lasting effects. In one vivid example, Weismantel (2013; 2015) has argued that intricate, imposing and mysterious stone carvings at the Early Horizon (c. 800-200 BC) site of Chavín de Huantar required much more than visual engagement from their audiences. While she does not refer to the Chavín artworks 
as affecting presences, she observes that Chavin's Lanzón, an intricately carved stone slab standing $4 \mathrm{~m}$ tall, embedded in the floor of an enclosed underground gallery (Fig. 10), could not be seen, deciphered, or understood unless the viewer moved in closely to see the incised details and then stepped back to try to take in the artwork as a whole. Such an encounter, in the semi-darkness of the underground tunnel, would have been physically demanding and memorable for visitors.

$<$ Figure 10 near here $>$

More generally, Chavín's objects generated 'a way of looking that oscillateslike the oscillating vision described by the shaman' (Weismantel 2015, 148). Encountering these carved stones, Weismantel suggests, required adopting multiple perspectives, shifting back and forth from human to animal; from hunter to prey; and from alive (and intact) to dead (and dismembered). Ultimately, she concludes, the '[p] erspectivism [of Viveiros de Castro] is ultimately about reciprocity of vision: the seer seen. Mutual apprehension does more than allow us to know one another: it teaches us to see ourselves through others' eyes' (Weismantel 2015, 30). Weismantel's discussion highlights active engagement by past people with art, as well as highlighting the ways that an animacy approach reveals boundaries between self and others that were fluid, made manifest momentarily, in this case, through a direct and close encounter. Certainly the dark, underground, constricted space in which the Lanzón rests reveals a concern for the kinds of heightened emotions and mystery that were likely to have been memorable.

\section{Discussion}

The aim of the preceding discussion has been to highlight different ways that a relational approach might deepen our understanding and knowledge of Andean art. I have argued that many crafted items in the Andes were portable objects intended 
to have a visual impact. They were used in daily life, in rituals, and sometimes placed in graves. In light of ethnographic evidence that Andean people view places on the landscape, as well as the things of the world, as potentially efficacious, agentive, or vital, imbued with sami, a life-force that circulates throughout the world (Allen 1998), objects made with care and skill take on special significance.

Interpreting the significance of an art object (or an assemblage of art objects) may require knowledge about the place of origin, the skills of one or more artisans, intrinsic properties deriving from the techniques of production or raw materials, as well as biographies of ownership, use, or intentional deposition (such as a burial or cache, or use as an offering).

To the extent that animacy perspectives redirect our attention to the relationships and linkages among objects, people and other (non-human) social actors, our analytical task becomes more challenging. Deposition is perhaps the most obvious way the archaeological record preserves information about relationships among objects (Zedeño 2008; 2013) and people. A burgeoning literature exploring bundles (Zedeño 2008; 2013), archives (Mills 2015) and caches (Murray and Mills 2013) indicates several avenues for implementing the kind of relational archaeologies advocated here (see, for example, the contributions to Watts 2013). More generally, exploring variation in deposition practices might reveal differential values of objects, patterns of individual or communal ownership (or use as heirlooms), or association with particular kinds of ritual (as, for example, the Calchaquí Valley urns).

In the Andes in particular, compelling evidence for extended interaction with ancestors over time, as well as diverse burial practices, attests to the enduring power of ancestors for structuring kin group affiliations (Lau 2015). Likewise, the links that connect people and ayllu to places or territories further materialize the longevity and social significance of these deep relationships. Here, specifically Andean principles of corporate insistence and abstraction in art, as discussed above, seem worth pursuing. For Inka-era relationships, the prominence of khipu design and zeq'e 
structure (as organizing principles) may be particularly relevant to more detailed analysis of the ways art mediates social relations.

\section{Conclusions}

A pilgrim arriving at Chavín, a farmer attending an Inka feast, or an individual subject to Wari rule would have encountered dramatic, colourful and memorable art. Intricately carved stonework, fine tapestry-woven tunics, gold and silver adornments and sculpted, painted ceramics belonged to a diverse assemblage of Andean artworks. Art-as well as quotidian items - could, at times, be perceived as powerful or animate, and artworks - and also objects we would certainly not call art-were drawn into complicated relationships of agency, influence and moral obligation in the pre-Hispanic Andes. Furthermore, given the hours of skill and labour that were dedicated to the making of a wide range of these art objects, it seems safe to conclude that their makers intended to evoke wide-ranging - and lasting - affective responses.

In this article, I have made a case for a relational approach to Andean art. I have suggested that four areas worth investigation in future research include insistence (repetition for emphasis); abstraction; the nature of networks or linkages among art objects, people, places and (non-human) actors; and the ways art objects influenced affective experience in the past.

To return to the wider questions orienting this collection of papers, I have argued that the term 'art' (as an analytic category) overlaps poorly with Andean categories of knowledge, sociality and material practice. I have, nevertheless, avoided an extended debate about the usefulness of the term art, instead focusing upon an approach that investigates (1) the making of art; (2) the intentions underlying artisans' efforts (to the extent that archaeologists can infer them); (3) the effects of art on audiences (or ritual participants) in the past; and (4) the varied roles of art in mediating social relations. 
Although this paper has focused on a richly varied assemblage of objects produced in the Andean past, the wider principles of a relational approach should be of use to those exploring ontology or animacy perspectives in other areas of the world. Perhaps most importantly, adopting a relational approach shifts attention away from individual objects, separated from their contexts and associations. As archaeologists refocus attention toward assemblages, or bundles (Zedeño 2008) and other deposits, we might also think critically about the ways contemporary museum displays encourage audiences to appreciate individual 'artworks' in isolation.

\title{
Notes
}

1. Discussing Inka art, D'Altroy $(2015,421)$ writes that ' $[t]$ he simplicity and repetition of the basic elements lent themselves to duplication by artisans throughout the empire. Designs on textiles and ceramics featured geometric forms in symmetric layouts, executed in bold, solid colors ... portraiture ... is not preserved in known Inca art. The successions of kings were recorded on panels and tapestries, but we do not know how representational they were.'

2. 'All known [textile production] techniques in the pre-industrial world - plus a few incredibly cumbersome types unique to the Andes-have been identified among the Andean repertoire' (Pasztory 1997, 63).

3. T'oqapu refers to the small geometric designs. The tunic is also reproduced in Allen (1998, 18, fig. 2).

4. See D'Altroy (2016) for further discussion of this point.

\author{
Elizabeth DeMarrais \\ Archaeology \& Anthropology \\ University of Cambridge \\ Downing Street
} Cambridge CB2 3DZ 


\section{References}

Abercrombie, T., 1998. Pathways of Memory and Power: Ethnography and history among an Andean people. Madison (WI): University of Wisconsin Press.

Allen, C.J., 1988. The Hold Life Has. Washington (DC): Smithsonian Press.

Allen, C.J., 1998. When utensils revolt: mind, matter, and modes of being in the PreColumbian Andes. RES: Anthropology and Aesthetics 33, 18-27.

Allen, C.J., 2002. The Inkas have gone inside: pattern and persistence in Andean iconography. RES: Anthropology and Aesthetics 37, 180-203.

Allen, C.J., 2015. The whole world is watching: new perspectives on Andean animism, in The Archaeology of Wak'as, ed. T. Bray. Boulder (CO): University of Colorado Press, 23-46.

Armstrong, R.P., 1971. The Affecting Presence. Urbana (IL): University of Illinois Press.

Ascher, M. \& R. Ascher, 1981. Code of the Quipu: A study in media, mathematics, and culture. Ann Arbor (MI): University of Michigan Press.

Barad, K., 2003. Posthumanist performativity: toward an understanding of how matter comes to matter. Signs: Journal of Women in Culture and Society 28, 801-31.

Bennett, J., 2010. Vibrant Matter: A political ecology of things. Durham (NC): Duke University Press.

Bennett, Wendell C. 1954. Ancient Arts of the Andes. Museum of Modern Art, New York, distributed by Simon and Schuster, New York.

Bergh, S.E., 2012. Tapestry-woven tunics, in Wari: Lords of the Ancient Andes, by S. Bergh. Cleveland (OH): Cleveland Museum of Art, 159-91.

Bray, T., 2003. Inka pottery as culinary equipment: food, feasting, and gender in imperial state design. Latin American Antiquity 14(1), 3-28.

Bray, T., 2009. An Archaeological Perspective on the Andean Concept of Camaquen: Thinking Through Late Pre-Columbian Ofrendas and Huacas. Cambridge Archaeological Journal 19:3, 357-66. 
Bray, T. (ed.), 2015. The Archaeology of Wak'as. Boulder (CO): University of Colorado Press.

Burger, R., 1992. Chavin and the Origins of Andean Civilization. London: Thames \& Hudson.

Burger, R., 2007. The emergence of figuration in early Peru, in Image and Imagination, eds. C. Renfrew \& I. Morley. Cambridge: McDonald Institute for Archaeological Research, 241-54.

Castillo Butters, L.J., H. Bernier, G. Lockard, J. Rucabado Yong, eds. 2008. Arqueología Mochica: Nuevos Enfoques. Actes \& Mémoires de l’Institut Français d'Études Andines, Vol. 21.

Castillo Butters, L.J. \& C.B. Donnan, 1994. La ocupación Moche de San José de Moro, Jequetepeque, in Moche, Propuestas y perspectivas, eds. S. Uceda C. \& E. Mujica B. (Travaux de l'IFEA 79.) Lima: Institut Français d'Études Andines, 93-146.

Cobo, B., [1653] 1990. Inka Religion and Customs (trans. R. Hamilton). Austin (TX): University of Texas Press.

Conklin, W.J. 2002. A khipu information string theory, in Narrative Threads: Accounting and Recounting in Andean Khipu, eds. J. Quilter \& G. Urton. Austin (TX): University of Texas Press, 53-86.

Conklin, W.J. \& J. Quilter, 2008. Chavín: Art, architecture and culture. Los Angeles (CA): Cotsen Institute of Archaeology.

Costin, C.L. 1998. Housewives, chosen women, skilled men: cloth production and social identity in the Late Prehispanic Andes, in Craft and Social Identity, eds. C. Costin \& R. Wright. (Special issue.) Archeological Papers of the American Anthropological Association 8(1), 123-141.

Curatola Petrocchi, M. 2008. La función de los oráculos en el imperio Inca, in Adivinación y oráculos en el mundo andino antiguo, eds. M. Curatola P. \& M.S. Ziólkowsk. Lima: Instituto Francés de Estudios Andinos and Pontificia Universidad Católica del Perú, 15-69.

D'Altroy, T., 2015. The Incas. Oxford: Wiley Blackwell. 
D'Altroy, T., 2016. Killing mummies: on Inka epistemology and imperial power, in Death Rituals, Social Order and the Archaeology of Immortality in the Ancient World, eds. C. Renfrew, M. Boyd \& I. Morley. Cambridge: Cambridge University Press, 404-24.

DeMarrais, E., 2011. Figuring the group. Cambridge Archaeological Journal 21(2), 16586.

DeMarrais, E., 2013a. Art as an affecting presence: infant funerary urns in PreHispanic northwest Argentina. World Art 3(1), 110-19.

DeMarrais, E., 2013b. Understanding heterarchy: crafting and social projects in PreHispanic northwest Argentina. Cambridge Archaeological Journal 23, 345-62.

DeMarrais, E., 2016. Making pacts and collective acts: the archaeology of coalition and consensus. World Archaeology 48(1), 1-13.

DeMarrais, E., in press. Ancestors, animacy, and archives: dynamics of heterarchy in pre-Hispanic northwest Argentina, in Powerful Places in the Andes, eds. J. Jennings \& E. Swenson. Albuquerque (NM): University of New Mexico Press.

DeMarrais, E., L.J. Castillo \& T. Earle, 1996. Ideology, Materialization, and Power Strategies. Current Anthropology 37, 15-31.

DeMarrais, E. \& J. Robb, 2013. Art makes society: an introductory visual essay. World Art 3(1), 3-22.

Diessl, W., 2004. Huantar, San Marcos, Chavín: Sitios arqueológicos en la Sierra de Ancash. Lima: Instituto Cultural Rvna.

Dissanayake, E., 1995. Homo Aestheticus. Seattle (WA): University of Washington Press.

Donnan, C.B., 2004. Moche Portraits from Ancient Peru. Austin (TX): University of Texas Press.

Gombrich, E., 1950. The Story of Art. London: Phaidon.

Gosden, Chris. 2004. Aesthetics, intelligence and emotions: implications for archaeology, in Rethinking Materiality, eds. E. DeMarrais, C. Gosden, and C. Renfrew. Cambridge: McDonald Institute for Archaeological Research, 33-42. 
Gose, P., 1994. Deathly Waters and Hungry Mountains. Agrarian ritual and class formation in an Andean town. Toronto: University of Toronto Press.

Gose, P., 1996. Oracles, divine kingship and political representation in the Inka state. Ethnohistory 43(1), 1-32.

Guaman Poma de Ayala, F., 1615-1616. El Primer Nueva Corónica y Buen Gobierno. Hirth, K. (ed.), 2009. Housework: Craft production and domestic economy in ancient Mesoamerica . Archeological Papers of the American Anthropological Association 19(1).

Jennings, J. \& E. Swenson (eds.), 2017. Powerful Places in the Andes. Albuquerque (NM): University of New Mexico Press.

Kroeber, A.L. \& D. Collier, 1998. The Archaeology and Pottery of Nazca, Peru (ed. P. Carmichael). London: Altamira Press.

Kubler, G., 1962. The Shape of Time. New Haven (CT): Yale University Press.

Kus, S., 2010. The Matter with Emotion (Comment on Rethinking Emotion and Material Culture). Archaeological Dialogues 17(2):167-72.

Lau, G. 2015. The dead and the longue durée in Peru's North Highlands, in Living with the Dead in the Andes, eds. I. Shimada and James L. Fitzsimmons. Tucson, University of Arizona Press, 200-244.

Lechtman, H., 1984. Andean value-systems and the development of prehistoric metallurgy. Technology and Culture 25, 1-36.

Mauss, M. 1969. The Gift: Forms and functions of exchange in archaic societies (trans. I. Cunnison). London: Routledge \& Kegan Paul.

McClelland, D., D. McClelland \& C. Donnan, 2007. Moche fineline painting from San José de Moro. Los Angeles (CA): Cotsen Institute of Archaeology.

Mills, B., 2015. Unpacking the House: Ritual Practice and Social Networks at Chaco, in Chaco Revisited, eds. C. C. Heitman and S. Plog. Tucson: University of Arizona Press, 249-271.

Murra, J., 1962. Cloth and its functions in the Inca State. American Anthropologist 64, 710-28. 
Murray, W.F. \& B.J. Mills, 2013. Identity communities and memory practices: relational logics in the U.S. Southwest, in Relational Archaeologies, ed. C. Watts. London: Routledge, 135-53.

Ogburn, D., 2004. Power in stone: the long-distance movement of building blocks in the Inca empire. Ethnohistory 51, 101-35.

Pasztory, E., 1990/1991. Still Invisible: The Problem of the Aesthetics of Abstraction for Pre-Columbian Art and Its Implications for Other Cultures. RES: Anthropology and Aesthetics 19/20: 104-36.

Pasztory, E., 1997. Andean Aesthetics, in The Spirit of Ancient Peru, ed. K. Berrin. London: Thames \& Hudson, 61-71.

Pasztory, E., 2005. Thinking with Things: Toward a New Vision of Art. Austin (TX): University of Texas Press.

Paul, A. (ed.), 1991. Paracas: Art and architecture. Iowa City (IA): University of Iowa Press.

Pillsbury, J., 2009. Reading art without writing: interpreting Chimú architectural sculpture, in Dialogues in Art History, from Mesopotamian to Modern: Readings for a new century, ed. E. Cropper. New Haven (CT): Yale University Press, 73-89.

Proulx, D.A. 2007. Nasca Ceramic Iconography: An overview. University of Massachusetts. (Reprinted with revised figures from The Studio Potter 29(1), 3743.)

Quilter, J., 1990. The Moche revolt of the objects. Latin American Antiquity 1(1), 42-65.

Quilter, J., 1997. The narrative approach to Moche iconography. Latin American Antiquity 8(2), 113-33.

Sawyer, A.R. [1963] 1982. Tiahuanaco tapestry design, in Peruvian Archaeology: Selected readings, eds. J. Rowe \& D. Menzel. Palo Alto (CA): Peek Publications, 165-76. (Reprinted from Textile Museum Journal 1(2), 27-38.)

Sillar, B., 2009. The social agency of things? Animism and materiality in the Andes. Cambridge Archaeological Journal 19(3), 367-77. 
Stone-Miller, R. \& G.F. McEwan, 1990/91. The representation of the Wari state in stone and thread: a comparison of architecture and tapestry tunics. RES: Anthropology and Aesthetics 19/20, 53-80.

Swenson, E., 2014. The materialities of place-making in the ancient Andes: a critical appraisal of the ontological turn in archaeological interpretation. Journal of Archaeological Method and Theory 22, 677-712.

Urton, G., 1997. The Social Life of Numbers: A Quechua ontology of numbers and philosophy of arithmetic. Austin (TX): University of Texas Press.

Urton, G., 2008. The Body of Meaning in Chavín Art, in Chavín: Art, Architecture, and Culture, eds. W.J. Conklin \& J. Quilter. Los Angeles, CA: Cotsen Institute of Archaeology, Monograph 61, 217-236.

Watts, C. (ed.), 2013. Relational Archaeologies. London: Routledge.

Weismantel, M., 2013. Inhuman eyes: looking at Chavín de Huantar, in Relational Archaeologies, ed. C. Watts. London: Routledge, 21-41.

Weismantel, M., 2015. Seeing like an archaeologist: Viveiros de Castro at Chavín de Huantar. Journal of Social Archaeology 15(2), 139-59.

Zedeño, M.N., 2008. Bundled worlds: the roles and interactions of complex objects from the North American Plains. Journal of Archaeological Method and Theory 15, 362.

Zedeño, M.N., 2013. Methodological and analytical challenges in relational archaeologies: a view from the hunting ground, in Relational Archaeologies, ed. C. Watts. London: Routledge, 117-35.

Zuidema, R.T., 1991. Guaman Poma and the art of empire: toward an iconography of Inca royal dress, in Transatlantic Encounters: Europeans and Andeans in the Sixteenth Century, eds. K.J. Andrien \& R. Adorno. Berkeley (CA): University of California Press, 151-202.

Zuidema, R.T., 1994. Guaman Poma between the arts of Europe and the Andes. Colonial Latin American Review 3(1-2), 37-85. 


\section{Author biography}

Elizabeth DeMarrais teaches in the Department of Archaeology at the University of Cambridge, where she is a Fellow of Churchill College. Co-director of the Material Culture Laboratory in the Department, she has long-standing research interests in archaeological theory, crafting, and art.

Figure 1. An Inka tunic composed of t'oqapu designs, AD 1430-1532. Wool and cotton, $90.2 \mathrm{~cm}$ (height)×77.2 cm (width). (Photograph: courtesy of Dumbarton Oaks, PreColumbian Collection, Washington, DC.)

Figure 2. Part of a frieze on a wall at Chan Chan, showing birds, fish and wave motifs. (Photograph: courtesy D. Beresford-Jones.)

Figure 3. Portion of a textile, Chimú, showing woven motifs similar to those on the frieze in Figure 2. (C) Michael C. Carlos Museum, Emory University. Photograph: Michael McKelvey.)

Figure 4. Chavin de Huantar stone carving from the New Temple patio, showing a fanged figure (identified as the primary deity) clutching shells, with braided snakes in place of hair.

Figure 5. Inka aríbalo. (Photograph: courtesy D. Beresford-Jones.)

Figure 6. Illustration of an individual holding an Inka khipu, from Guaman Poma de Ayala (1615-1616, 360). 
Figure 7. Aerial photograph of Wari site of Pikillacta. (Courtesy of the Servicio Aereo Naciónal, Peru.)

Figure 8. Middle Horizon tunic, probably south coast (Wari), $86.4 x$ $116.8 \mathrm{~cm}$, camelid fibres. Metropolitan Museum of Art, Gift of Rosetta and Louis Slavitz, 1986 (1986.488.3). The photo is in the public domain, from www.metmuseum.org.

Figure 9. Infant burial urn, Museo Arqueológico de Cachi, from the northern Valle Calchaquí. (Photograph: E. DeMarrais.)

Figure 10. The Lanzón at Chavin de Huantar, in situ in the underground gallery. (Photograph: courtesy D. Beresford-Jones.) 